\title{
HUBUNGAN ANTARA KUALITAS LAYANAN PERPUSTAKAAN UNDIKSHA DAN KEPUASAN PENGGUNANYA
}

\author{
Nyoman Oka Dharma ${ }^{1}$, Ni Wayan Sri Budi ${ }^{2}$, I Gede Ngurah Sugata ${ }^{3}$ \\ UPT. Perpustakaan Universitas Pendidikan Ganesha \\ Singaraja, Indonesia \\ e-mail: hoka_moka@yahoo.com
}

\begin{abstract}
Abstrak
Penelitian ini bertujuan untuk mengetahui hubungan kualitas pelayanan Perpustakaan Undiksha dengan kepuasan penggunanya. Pengukuran kualitas pelayanan berdasarkan pada lima dimensi kualitas pelayanan yang dikemukakan oleh Parasuraman,dkk, yaitu bukti langsung (tangible), keandalan (reliability), daya tanggap (responsiveness), jaminan (assurance), dan empati (empathy). Penelitian ini menggunakan pendekatan ex post facto. Sampel penelitian ini adalah mahasiswa Undiksha yang berkunjung ke perpustakaan Undiksha sebanyak 60 orang. Teknik pengambilan sampel menggunakan accidental random sampling. Data utama dalam penelitian ini dikumpulkan dengan menggunakan kuisioner, sedangkan data pendukungnya dikupulkan dengan observasi dan wawancara. Data yang telah terkumpul dianalisis dengan menggunakan analisis kuantitatif. Penelitian ini menemukan bahwa terdapat hubungan kualitas pelayanan terhadap kepuasan pengunjung perpustakaan Undiksha dilihat dari aspek bukti langsung (katagori agak rendah); kehandalan (katagori cukup); cepat tanggap (katagori tinggi); kepastian (katagori agak rendah); dan empati (katagori tinggi). Secara umum besarnya korelasi antara kualitas pelayanan terhadap kepuasan pengunjung $r=0,952$ sedangkan kontribusinya sebesar 0,906 atau $90,60 \%$, dimana hal ini diinterpretasikanke dalam katagori sangat kuat
\end{abstract}

Kata kunci : kualitas pelayanan, kepuasan pengguna

\begin{abstract}
The study was intended to know the corellation between the service quality of Undiksha Library with the user satisfaction. The quality was measured by using five dimensions of libray quality by Parasuraman, they are (tangible), (reliability), (responsiveness), (assurance), and (empathy). This study used ex post facto approach and the sample was 60 students of Ganesha University who visitted the library. The sample was choosen using accidental random sampling technique. The primary data was collected by using questionnaire while the supporting data was gathered through observation and interview. The data was analyze quantitatively. The result shows that there is significant relationship of service quality toward the user satisfaction which can be seen from the tangibles aspect (category quite low); reliability aspect (category fair); responsiveness (category high); assurance (quite low), and empathy (category high). Overall, the correlation in general between the service quality of Undiksha Library with the user satisfaction is $r=0.952$ and the contribution is 0.906 or $90.60 \%$ which is interpreted as very strong.
\end{abstract}

Key words: Service quality, user satisfaction,

\section{PENDAHULUAN}

Sebagai suatu lembaga pendidikan tinggi, perguruan tinggi dikelola dengan berpedoman pada kepentingan sivitas akademika yang terdiri dari mahasiswa, tenaga pengajar dan karyawan. Dalam pelaksanaannya, perguruan tinggi harus dilengkapi dengan beberapa fasilitas guna mendukung keberhasilan tujuan dari program perguruan tinggi. Salah satu 
fasilitas pendukung keberhasilan suatu perguruan tinggi adalah melalui penyediaan perpustakaan yang turut melaksanakan Tri Dharma melalui penyediaan, pengorganisasian, dan memberikan pelayanan kepada pengguna perpustakaan.

Sesuai dengan fungsinya, perpustakaan perguruan tinggi dituntut untuk memberikan pelayanan yang berkualitas jasa tinggi, yaitu layanan yang dapat memenuhi kebutuhan dan harapan pengguna perpustakaan. Perpustakaan sebagai lembaga penyedia jasa diharapkan dapat memenuhi kepuasan penggunanya dengan penyediaan berbagai sumber informasi dan memberikan pelayanan yang berkualitas.

Parasuraman, Zeithaml, dan Berry dalam Samosir (2006) menyatakan bahwa "kualitas pelayanan adalah perbandingan antara pelayanan yang diharapkan konsumen dengan pelayanan yang diterimanya." Dengan kata lain apabila pelayanan yang diterima atau dirasakan sesuai dengan yang diharapkan oleh pengguna perpustakaan maka kualitas pelayanan dipersepsikan baik dan memuaskan. Jika jasa atau pelayanan yang diterima melampaui harapan pengguna, maka kualitas pelayanan dipersepsikan sebagai kualitas ideal. Tetapi sebaliknya, jika pelayanan yang diterima lebih rendah dari yang diharapkan maka kualitas pelayanan harus dimulai dari kebutuhan pengguna dan berakhir pada tanggapan pengguna. Tanggapan pengguna terhadap kualitas pelayanan itu sendiri merupakan penilaian menyeluruh terhadap keunggulan suatu pelayanan.

Model Kualitas pelayanan yang popular dan hingga kini banyak dijadikan sebagai acuan dalam riset pemasaran jasa adalah model servqual (service quality) yang dikembangkan oleh Parasuraman, Zeithaml, dan Berry. Model Servqual ini kemudian dimodifikasi dan diaplikasikan ke dalam jasa layanan perpustakaan, kemudian disebut sebagai Libqual (Library Quality). Dalam Libqual, yang dijadikan acuan untuk mengukur kualitas pelayanan adalah sebagai berikut : (1) kehandalan (reliability), yaitu kemampuan perpustakaan dalam melaksanakan jasa yang dijanjikan; (2) daya tanggap (responsiveness), yang menunjukkan kemauan untuk membantu pelanggan dan memberikan jasa dengan cepat atau tanggap; (3) jaminan (assurance), menunjukkan sejauhmana pengetahuan dan kesopanan pustakawan serta kemampuan menciptakan image atau persepsi yang baik bagi perpustakaan dengan menumbuhkan kepercayaan dan keyakinan di benak pengguna terhadap perpustakaan; (4) empati (empathy), sebagai syarat untuk peduli dan memberikan perhatian secara pribadi bagi pengguna; dan (5) bukti fisik (tangibles), berupa penampilan fasilitas fisik, peralatan, personel, dan media komunikasi.

Dimensi-dimensi inilah yang harus diperhatikan oleh pengelola perpustakaan, sehinggga berbagai pengalaman yang dapat menyebabkan tidak nyamannya pengguna perpustakaan tidak akan terjadi.

Universitas Pendidikan Ganesha saat ini memiliki tiga gedung perpustakaan, yaitu perpustakaan pusat, perpustakaan pascasarjana, yang keduanya berada di Singaraja, dan perpustakaan PGSD di Denpasar. Berdasarkan pengamatan visual dari pustakawan di tiga perpustakaan tersebut yag didukung oleh data kunjungan mahasiswa pada buku pengunjung diketahui bahwa perpustakaan pascasarjana memiliki tingkat kunjungan paling rendah.

Banyak faktor yang diduga menjadi penyebab rendahnya tingkat kunjungan dan pemanfaatan perpustakaan oleh mahasiswa, diantaranya mahasiswa program tersebar di beberapa kota di Singaraja, sehingga dari segi jarak mereka merasa jauh untuk berkunjung ke perpustakaan; kurangnya sosialisasi cara penggunaan teknologi informasi dalam pencarian informasi; kurangnya layanan kepada pengunjung khususnya sarana dan prasarana pendukung dalam memperoleh informasi yang dibutuhkan; kurang nyamannya gedung atau ruang perpustaaan 
dari segi luas, mebeler, dan jenis koleksi; serta penugasan dari dosen kepada mahasiswa untuk mendayagunakan perpustakaan belum optimal. Hal tersebut disebabkan karena belum adanya sinergi atau kerjasama yang dibangun pihak pendidik/dosen dengan pengelola perpustakaan, baik dari segi penyediaan koleksi maupun buku pendukung lainnya sehingga terdapat kesan bahwa buku-buku yang dikoleksi tidak sesuai dengan kebutuhan dosen maupun mahasiswa.

Dengan bertitik tolak dari latar belakang yang telah dikemukakan, maka rumusan masalah dalam penelitian ini adalah Apakah ada hubungan antara bukti langsung (tangibles), kehandalan (reliability), cepat tanggap (responsiveness), kepastian/ jaminan (assurance), empati (Empaty), dan kepuasan pengunjung yang menggunakan jasa layanan di Perpustakaan Undiksha, serta apakah ada hubungan antara kualitas layanan dan kepuasan pengunjung yang menggunakan jasa layanan di Perpustakaan Undiksha?

Adapun tujuan dari penelitian ini adalah untuk Mendeskripsikan hubungan antara bukti langsung (Tengibles), kehandalan (reliability), cepat tanggap (responsiveness), kepastian/jaminan (assurance), empati (Empaty), dan kepuasan pengunjung yang menggunakan jasa layanan di Perpustakaan Undiksha, serta menganalisis hubungan antara kualitas pelayanan dan kepuasan pengunjung yang menggunakan jasa layanan di Perpustakaan Undiksha.

Model Kualitas jasa layanan perpustakaan yang sangat populer dan hingga kini banyak dijadikan acuan dalam riset pemasaran adalah Model LIBQUAL (singkatan dari library quality) yang dikembangkan oleh Parasuraman, Zeithhaml, dan Berry. Model ini meliputi analisis terhadap lima kesenjangan (gap) yang berpengaruh terhadap kualitas jasa, sebagai penyebab kegagalan service delivery. Adapun lima kesenjangan tersebut yaitu: a. Kesenjangan antara harapan pengguna dan persepsi pengelola. Pengelola tidak selalu dapat merasakan apa yang diinginkan oleh para pengguna secara tepat

b. Kesenjangan antara persepsi pengelola dan spesifikasi kualitas jasa. Mungkin pengelola mampu merasakan secara tepat apa yang diinginkan oleh para pelanggan, namun tidak menyusun suatu standar kinerja tertentu.

c. Kesenjangan antara spesifikasi jasa dan penyampaian jasa. Pustakawan mungkin kurang dilatih atau bekerja melampaui batas dan tidak dapat serta tidak mau untuk memenuhi standar

d. Kesenjangan antara penyampaian jasa dan komunikasi internal. Harapan pengguna dipengaruhi oleh pernyataanpernyataan yang dibuat oleh wakil (representative) dan iklan perpustakaan

e. Kesenjangan antara jasa yang dirasakan dan jasa yang diharapkan.

Ada beberapa faktor yang dapat mempengaruhi kepuasan pelanggan antara lain:

a. Nilai (value) merupakan pengkajian secara menyeluruh manfaat dari suatu produk, yang didasarkan pada presepsi pelanggan atas apa yang telah diterima oleh pelanggan dan telah diberikan oleh produk tersebut. Kreteeria nilai bagi pelanggan dapat digambarkan sebagi berikut:

Nilai bagi pelanggan $=$ kualitas/biaya $\mathrm{x}$ layanan/waktu.

b. Daya saing, suatu produk akan memiliki daya saing agar jika memiliki keunggulan. Keunggulan produk jasa terletak pada keunikan dan kualitas pelayanan produk jasa yang disesuikan dengan manfaat serta pelayanan yang dibutuhkan oleh pelanggan.

c. Persepsi, pelanggan merupakan sebuah proses dimana individu memilih, mengorganisasikan, serta mengartikan stimulus yang diterima melalui alat 
inderanya menjadi satu makna. Faktorfaktor yang berpengaruh terhadap persepsi pelayanan suatu jasa adalah harga, citra, tahap pelayanan, momen pelayanan.

d. Harga, harga yang rendah menimbulkan persepsi produk tidak berkualitas, harga yang tinggi menimbulkan persepsi produk tersebut berkualitas.

e. Citra, citra yang buruk menimbulkan persepsi produk tidak berkualitas sehingga pelanggan mudah marah untuk kesalahan sekecil apapun. Citra yang baik menimbulkan persepsi produk yang berkualitas sehingga pelanggan memanfaatkan suatu kesalahan.

f. Tahap pelayanan, kepuasan pelanggan ditentukan oleh beberapa jenis pelayanan yang didapatkan oleh pelangan selama mengunakan beberapa tahapan pelayanan tersebut.

g. Momen pelayanan (situasi), situasi pelayanan dikaitkan dengan kondisi internal pelangan sehingga mempengaruhi kinerja pelayanan. Persepsi pelanggan terhadap pelayanan ditentukan oleh: pelayanan, proses pelayanan, lingkungan fisik dimana pelayanan diberikan.

h. Tingkat kepentingan pelangan, suatu keyakinan pelanggan sebelum mencoba atau membeli suatu produk yang akan dijadikan standar acuan dalam menilai kinerja produk jasa tersebut.

i. Model kesenjangan kepuasan pelanggan, kesenjangan merupakan ketidaksesuaian antara pelayanan yang dipersepsikan dan pelayanan yang diharapkan.

j. Strategi kepuasan pelanggan, penyusunan strategi untuk meningkatkan kepuasan pelanggan harus mempertimbangkan dua strategi pemasaran yaitu defensive dan offensive marketing. Defensive marketing adalah mempertahankan pelanggan yang sudah ada misalnya: meningkatkan voleme pembelian kembali, menerapkan strategi harga premiaum dam melakuakn promosi. Sedangkan offensive marketing adalah mencari pelanggan baru yaitu meningkatkan pangsa pasar, meningkatkan citra produk.

\section{METODE}

Penelitian ini menggunakan pendekatan ex post facto. Data yang digunakan dalam penelitian ini yaitu data primer, di mana data yang didapat langsung oleh peneliti berkaitan dengan diadakannya penelitian ini, seperti jawaban pengguna perpustakaan dalam kuisioner yang disebarkan, dan data sekunder yaitu data yang bukan hasil dari peneliti melainkan diperoleh dari hasil peneliti dan pengolahan dari orang lain, seperti statistic jumlah kunjungan, saran dan keluhan pengguna dalam buku tamu, dll.

Dalam penelitian ini populasi yang digunakan adalah seluruh mahasiswa Undiksha yang berasal dari 6 (enam) fakultas, yaitu Fakultas Bahasa dan Seni (FBS), Fakultas IImu Pendidikan (FIP), Fakultas IImu Sosial (FIS), Fakultas Matematika dan IPA (FMIPA), Fakultas Tehnik dan Komputer (FTK), dan Fakultas Olahraga dan Kesehatan (FOK).

Pengguna yang dijadikan sampel adalah mahasiswa Undiksha yang berkunjung ke perpustakaan Undiksha. Pengambilan sampel menggunakan teknik accidental random sampling. Jumlah sampel yang ditentukan adalah sebanyak 60 orang.

Dalam penelitian ini terdapat enam variable yang akan diukur. Untuk menjelaskan variable maka perlu definisi oprasional dari masing-masing variable sebagai upaya pemahaman dalam penelitian.

1) Variabel bukti fisik/tangibles (X1) yaitu meliputi fasilitas fisik, perlengkapan, penampilan. Indikatornya adalah fasilitas secara visual, bahan pustaka yang dimiliki, profesionalisme pustakawan, teknologi dan peralatan

Jurnal IImu Sosial dan Humaniora | 225 
2) Variabe kehandalan/reliability (X2) yaitu kemampuan memberikan pelayanan dengan segera dan akurat sesuai dengan yang dijanjikan dengan indikator: prosedur pelayanan, prosedur kerja petugas perpustakaan, penyelesaian masalah dan sikap pustakawan

3) Variabel cepat tanggap/ responsiveness (X3) yaitu kesediaan dan kesiapan petugas perpustakaan untuk membantu pengunjung dan memberikan layanan dengan tanggap. Indikatornya adalah mengutamakan kepentingan pengunjung dan tanggap atas keluhan pengunjung

4) Variabel kepastian/assurance (X4) yaitu dapat dipercaya, bebas dari keragu-raguan. Indikatornya adalah menimbulkan kepercayaan dan keyakinan pengunjung terhadap perpustakaan serta keamanan menggunakan perpustakaan

5) Variabel empati/empathy (X5) yaitu meliputi hubungan, komunikasi, perhatian pribadi dan memahami kebutuhan pengunjung. Indikatornya adalah perhatian kepada pengunjung, serta merespons kebutuhan pengunjung.

6) Variabel kualitas Layanan ( $Y$ ) yaitu suatu penilaian yang diberikan oleh pengunjung setelah menggunakan jasa layanan perpustakaan. Indikatornya adalah penggunaan perpustakaan secara berulang, menginformasikan kepada pengguna lain untuk menggunakan jasa perpustakaan. Instrumen Penelitian

\section{a. Kuisioner (sebagai pengumpul data utama)}

Dalam penelitian ini metode yang digunakan untuk memperoleh informasi dari responden adalah berbentuk angket atau kuisioner. Jenis kuisioner ini adalah kuisioner tertutup dengan skala Likert. Kuisioner tertutup yaitu kuisioner yang sudah disediakan jawabannya sehingga responden tinggal memilih pada kolom yang sudah disediakan dengan memberi tanda silang $(\mathrm{x})$ atau tanda centang $(\sqrt{ })$. Adapun sebagai alasan digunakannya kuisioner tertutup karena jenis kuisioner tersebut memberikan kemudahan kepada responden dalam memberikan jawaban, lebih praktis dan sistematis.

Kuisioner untuk mengumpulkan data penelitian ini dikembangkan oleh Parasurama, dkk (1990) yang mencakup lima aspek tentang persepsi dan harapan pengunjung terhadap kualitas layanan perpustakaan Undiksha dan perpustakaan secara umum, yaitu bukti fisik, kehandalan, cepat tanggap, kepastian, dan empati, yang masing-masing akan dikembangkan menjadi 1 (satu) kuesioner.

b. Wawancara dan observasi (sebagai data pendukung)

Data penelitian ini digunakan sebagai bahan untuk melakukan pembahasan atas hasil pengujuan hipotesis

1. Wawancara

Wawancara dilakukan setelah pengunjung mengisi kuisioner. Tujuannya untuk memastikan informasi yang diberikan dilakukan dengan sungguhsungguh.

2. Observasi.

Observasi merupakan teknik pengumpulan data dengan dilakukannya pengamatan dari peneliti secara langsung maupun tidak langsung terhadap objek penelitiannya (Umar, 1998:51). Dalam penelitian ini metode observasi digunakan untuk menjaring data tentang kualitas pelayanan perpustakaan dengan melihat secara langsung proses layanan yang diberikan pustakawan kepada pengunjung

Data yang dianalisis adalah data yang diperoleh dari kuesioner yang diberikan kepada sejumlah responden. Metode ini digunakan dengan tujuan untuk memperoleh hasil dari menguraikan pertanyaanpertanyaan yang diambil dari indikatorindikator variabel-variabel yang diteliti.

\section{Pengujian Persyaratan Analisis}

Uji Persyaratan analisis dimaksudkan untuk menguji apakah data yang terkumpul memenuhi persyaratan untuk dianalisis. 
Statistik yang digunakan dalam analisis data penelitian ini adalah teknik analisis korelasi dan analisis regresi. Sebelum menggunakan analisis tersebut, terlebih dahulu dilakukan pengujian persyaratan analisis. Persyaratan yang harus dipenuhi adalah: normalitas sebaran data, linieritas garis regresi, dan multikolinieritas (Sudjana, 1991)

\section{a. Uji normalitas sebaran data}

Uji normalitas digunakan untuk apakah dalam dalam sebuah model regresi, variabel dependen, variabel independen, atau keduanya mempunyai distribusi normal ataukah tidak. Model regresi yang baik adalah distribusi data normal atau mendekati normal. Deteksi normalitas dengan melihat penyebaran data (titik) ada sumbu diagonal dari grafik. Dasar dari pengambilan keputusan sebagai berikut: a) jika data menyebar di sekitar garis diagonal dan mengikuti arah garis diagonal, maka model regresi memenuhi asumsi normalitas; b) jika data menyebar jauh dari garis diagonal dan atau tidak mengikuti arah garis diagonal, maka model regresi tidak memenuhi asumsi normalitas

\section{b. Uji Linieritas dan Keberartian Koefisien Regresi}

Uji linieritas dilakukan untuk mengetahui bentuk hubungan antara variabel terikat dengan masing-masing variabel bebas. Pedoman untuk melihat kelinieran adalah dengan mengkaji lajur Deviation From Linearity dari model Mean, sedangkan untuk melihat keberartian arah regresinya berpedoman pada lajur linearity. Statistik yang dihasilkan dari modul tersebut adalah statistik F.

Kriteria yang digunakan uji linieritas adalah pada lajur Deviation From Linearity, jika $F$ hitung $<F$ tabel $(p>0.005)$ maka dinyatakan bahwa bentuk regresinya linier, dan sebaliknya jika $F$ hitung $>F$ tabel $(p<$ 0.005) maka regresinya tidak linier. Sedangkan ujikeberartian koefisien regresi, pada lajur Linearity, jika jika $F$ hitung $>F$ tabel ( $p>0.005)$ maka koefisien regresinya dinyatakan berarti, dan sebaliknya jika jika $F$ hitung $<F$ tabel $(p<0.005)$ dinyatakan koefisiennya tidak berarti. Untuk penghitungan dilakukan dengan bantuan komputer.

\section{c. Uji Multikolinieritas}

Uji multikolinieritas digunakan untuk menguji apakah pada model regresi ditemukan adanya korelasi antar variabel independen. Jika terjadi korelasi, dinamakan terdapat problem multikolinieritas (multiko). Deteksi adanya multikolinieritas dilihat dari besaran Variance Inflation Factor (VIF) dan Tolerance dari tabel hasil olahan data kuisioner. Untuk mengetahui suatu model regresi yang bebas multiko adalah: a) mempunyai nilai VIF di sekitar angka I; b) mempunyai angka, toleransi mendekati.

\section{d. Uji Heterokedasitas}

Uji Heterokedasitas digunakan untuk menguji apakah dalam sebuah regresi, terjadi ketidaksamaan varians dari residual dari satu pengamatan ke pengamatan yang lain. Jika varians dari residual dari pengamatan ke pengamatan yang lain tetap, maka disebut homokedasitas. Dan jika varians berbeda maka disebut heterokedasitas.

Model regresi yang baik adalah tidak terjadi heterokedasitas. Deteksi dengan melihat ada tidaknya pola tertentu pada grafik dimana sumbu $X$ dan $Y$ yang telah diprediksi, dan sumbu $X$ adalah residual $(Y$ prediksi $Y$ sesungguhnya) yang telah distandarisasi. Dasar pengambilan keputusan: a) jika ada pola tertentu seperti titik-titik yang membentuk suatu pola tertentu dan teratur (bergelombang, melebar kemudian menyempit) maka telah terjadi heterokedasitas; b) jika tidak ada pola yang jelas, serta titik-titik yang menyebar di atas dan di bawah angka 0 pada sumbu $\mathrm{Y}$, maka tidak terjadi heterokedasitas.

\section{e. Uji Autokorelasi}

Autokorelasi terjadi dalam regresi apabila dua error $\varepsilon t-1$ dan $\varepsilon t$ tidak

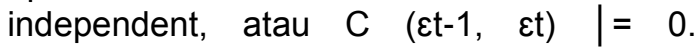
Autokorelasi biasanya terjadi apabila pengukuran variabel dilakukan dalam interval atau waktu tertentu hubungan 
antara et dengan $\varepsilon t-1$ dapat dinyatakan sebagai berikut:

$$
\varepsilon t=p \varepsilon t-1+v t
$$

$p$ menyatakan koefisien autokorelasi populasi. Apabila $p=0$ maka autokorelasi tidak terjadi. Apabila autokorelasi terjadi, maka $\mathrm{p}$ akan mendekati +1 atau -1 . Menduga terjadi tidaknya autokorelasi dengan diagram antara grafik antara $\varepsilon t$ dengan $\varepsilon t-1$ sangat sulit. Deteksi autokorelasi umumnya dilakukan dengan uji statistik Durbin Watson

\section{UJI HIPOTESIS}

Pengujian hipotesis dilakukan sebagai upaya untuk mencapai tujuan penelitian. Data yang dikumpulkan, dianalisis dengan menggunakan analisis kuantitatif yang sebagai berikut :

\section{Analisis Regresi Sederhana}

Analisis ini digunakan untuk mengetahui ada tidaknya pengaruh antara dua variabel yaitu variabel bebas (X1 adalah bukti langsung, X2 adalah kehandalan, X3 adalah daya tanggap, $X 4$ adalah jaminan atau kepastian, dan X5 adalah empati) dengan variabel terikat atau tingkat kepuasan pengguna $(\mathrm{Y})$. Dengan rumus sebagai berikut:

\section{$\mathbf{Y}=\mathbf{a}+\mathbf{b x}$}

Dimana:

$Y=$ variabel terikat

$\mathrm{X}=$ variabel bebas

$\mathrm{a}=$ nilai konstanta $\mathrm{b}=$ nilai koefisien dari variabel bebas

\section{Analisis Korelasi Sederhana}

Analisis ini digunakan untuk mengetahui derajat hubungan antara variabel bebas $(X)$ terhadap variabel terikat (Y) dengan persamaan. Derajat hubungan antara varibel bebas terhadap variabel terikat dirumuskan sebagai berikut:

$$
r=\frac{n \sum X Y-\left(\sum X\right)\left(\sum Y\right)}{\sqrt{\left\{n \sum X^{2}-(\Sigma X)^{2}\right\}\left\{n \Sigma Y^{2}-(\Sigma Y)^{2}\right\}}}
$$

Dimana:

$$
\begin{array}{ll}
r=1 & \begin{array}{l}
\text { hubungan } X \text { dan } Y \text { sempurna } \\
\text { dan positif (mendekati hubungan } \\
\text { kuat positif) }
\end{array} \\
r=-1 & \begin{array}{l}
\text { hubungan } X \text { dan } Y \text { sempurna } \\
\text { dan negatif (mendekati }-1
\end{array} \\
r=0 & \begin{array}{l}
\text { hubungan kuat dan negatif) } \\
\text { hubungan } X \text { dan } Y \text { lemah sekali } \\
\text { atau tidak ada hubungannya. }
\end{array}
\end{array}
$$

$$
\begin{aligned}
& \text { Keterangan: } \\
& r=\text { koefisien korelasi } \\
& X=\text { variabel bebas } \\
& Y=\text { variabel terikat } \\
& N=\text { jumlah sampel }
\end{aligned}
$$

Kreteria yang digunakan untuk menentukan derajat hubungan yang terjadi antara variabel bebas dan variabel terikat adalah sebagai berikut:

\begin{tabular}{|c|l|}
\hline Besarnya Nilai $\mathbf{r}$ & \multicolumn{1}{c|}{ Interpretasi } \\
0 & Tidak berkolerasi \\
$0,01 \mathrm{~s} / \mathrm{d} 0,20$ & Sangat rendah \\
$0,21 \mathrm{~s} / \mathrm{d} 0,40$ & Rendah \\
$0,41 \mathrm{~s} / \mathrm{d} 0,60$ & Agak rendah \\
$0,61 \mathrm{~s} / \mathrm{d} 0,80$ & Cukup \\
$0,81 \mathrm{~s} / \mathrm{d} 0,99$ & Tinggi \\
1 & Sangat tinggi \\
\hline
\end{tabular}

\section{Analisis Determinasi}

Analisis koefisien determinasi digunakan untuk mengetahui besarnya pengaruh variabel bebas (kualitas pelayanan) terhadap variabel terikat (kepuasan pengguna) yang diyatakan dalam persentase. Nilai determinasi dirumuskan sebagai berikut: 
$D=r^{2} \times 100 \%$

Dimana:

$\mathrm{D}=$ koefisien determinasi

$r^{2}=$ kuadrat koefisien korelasi berganda

\section{a. Analisis Regresi Berganda}

Analisis ini digunakan untuk mengetahui pengaruh dari variabel-variabel kualitas pelayanan secara bersamaan terhadap kepuasan pengguna perpustakaan Untuk analisis ini digunakan rumus:

$Y=a+b 1 X 1+b 2 X 2+b 3 X 3+b 4 X 4+b 5 X 5$

Dimana:

$Y=$ kepuasan pengguna

b1 = koefisien regresi dari X1

$\mathrm{A}=$ nilai konstanta

$\mathrm{b} 2=$ koefisien regresi dari $\mathrm{X} 2$

$\mathrm{X} 1=$ tangibles (bentuk Fisik)

b3 = koefisien regresi dari X3

$\mathrm{X} 2$ reliability (kehandalan)

b4 = koefisien regresi dari $\mathrm{X} 4$

$\mathrm{X} 3=$ responsiveness (daya tanggap)

b5 = koefisien regresi dari X5

$\mathrm{X} 4$ = assurancy (jaminan)

$\mathrm{X} 5$ = empathy (empati)

\section{b. Analisis Korelasi Berganda}

Analisis ini digunakan untuk mengetahui kuat lemahnya hubungan antar variabel-variabel dari kualitas pelayanan terhadap variabel terikat (kepuasan pengguna). Dengan bantuan SPSS, nilai $r$ (koefisien korelasi) dapat dicari, kemudian ditentukan interpensi tingkat hubungannya berdasarkan interval sebagai berikut:
Interval $0,00-0,19$ tingkat hubungannya sangat rendah

Interval $0,20-0,39$ tingkat hubungannya rendah

Interval $0,40-0,59$ tingkat hubungannya sedang

Interval $0,60-0,79$ tingkat hubungannya kuat

Interval 0,80 - 1,00 tingkat hubungannya sangat kuat

\section{c. Analisis Determinasi}

Analisis ini digunakan untuk mengetahui besarnya pengaruh variabel bebas (kualitas pelayanan) terhadap variabel terikat (kepuasan pengguna) yang diyatakan dalam persentase. Nilai determinasi dirumuskan sebagai berikut:

$D=r^{2} \times 100 \%$

Dimana:

$\mathrm{D}=$ koefisien determinasi

$r^{2}=$ koefisien korelasi

\section{HASIL DAN PEMBAHASAN \\ Hasil Analisis Deskriptif Data kualitas pelayanan}

Untuk mendapatkan gambaran mengenai karakteristik distribusi skor dari variabel kualitas pelayanan, berikut disajikan skor tertinggi, skor terendah, harga rerata, simpangan baku, varian, median, modus, dan histogram variabel kualitas pelayanan. Di bawah ini disajikan rangkuman statistik seperti pada Tabel 4.1. 
Tabel 4.1 Rangkuman Statistik Variabel kualitas pelayanan

\begin{tabular}{|c|c|}
\hline Statistik & Kualitas pelayanan \\
\hline Mean & 116,83 \\
\hline Median & 118,00 \\
\hline Modus & 125 \\
\hline Standar Deviasi & 6,850 \\
\hline Varians & 46,921 \\
\hline Rentangan & 23 \\
\hline Skor Minimum & 102 \\
\hline Skor Maksimum & 125 \\
\hline Jumlah & 7010 \\
\hline
\end{tabular}

Berdasarkan data pada tabel tersebut, maka dapat dijelaskan sebagai berikut.Dari hasil pengukuran terhadap responden menunjukkan bahwa skor tertinggi yang dicapai adalah 125 sedangkan skor terendah yang dicapai adalah 102. Rata-rata skor variabel kualitas pelayanan sebesar 116,83 dengan standar deviasi sebesar 6,85. Untuk mengetahui persebaran skor kualitas pelayanan di Perpustakaan Undiksha, dapat dilihat seperti Gambar 4.1.

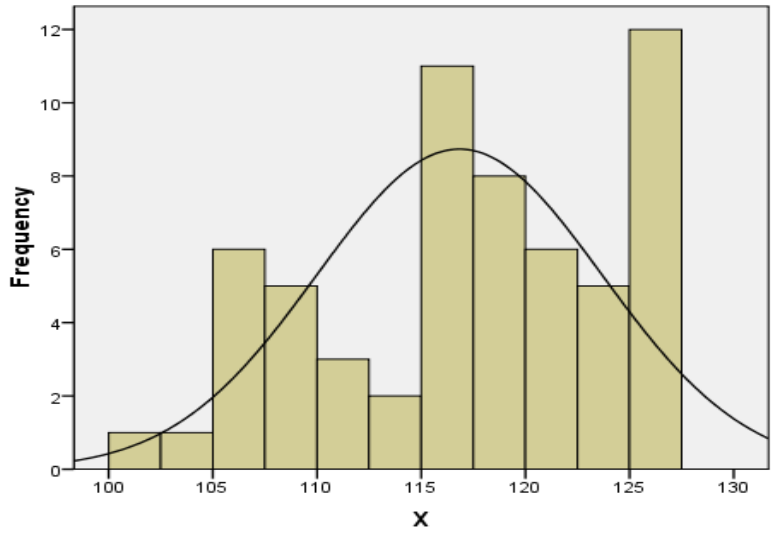

Gambar 4.1 Persebaran skor kualitas pelayanan

Hasil Analisis Deskriptif Data kepuasan pengunjung

Untuk mendapatkan gambaran mengenai karakteristik distribusi skor dari variabel kepuasan pengunjung, berikut disajikan skor tertinggi, skor terendah, harga rerata, simpangan baku, varian, median, modus, dan histogram variabel kepuasan pengunjung.

Berdasarkan data pada tabel tersebut, maka dapat dijelaskan sebagai berikut.Dari hasil pengukuran terhadap responden menunjukkan bahwa skor tertinggi yang dicapai adalah 50 sedangkan skor terendah yang dicapai adalah 38. Rata-rata skor variabel kepuasan pengunjung sebesar 46,18 dengan standar deviasi sebesar 3,352. Untuk mengetahui persebaran skor kepuasan pengunjungdi Perpustakaan Undiksha, dapat dilihat seperti Gambar 4.2. 


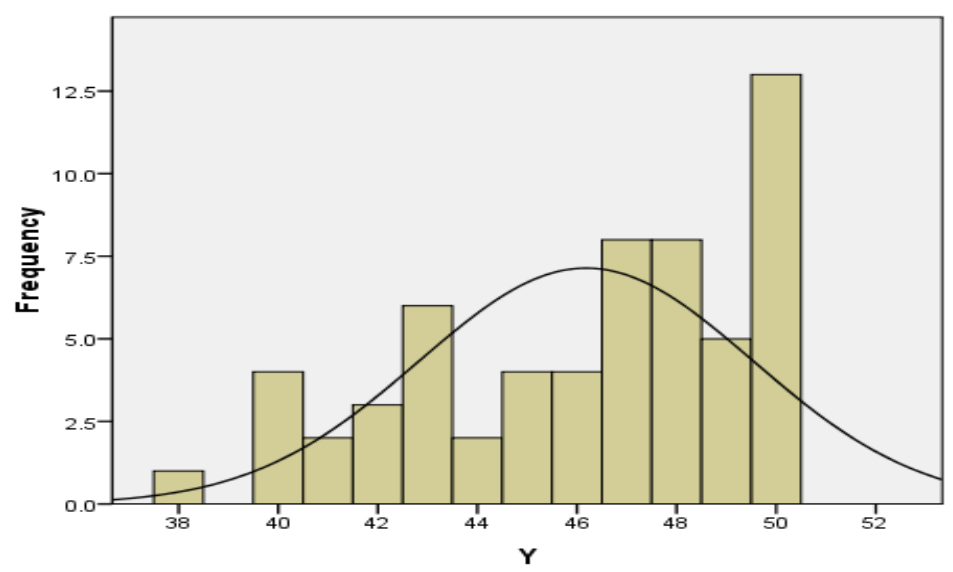

Gambar 4.2 Persebaran skor kepuasan pengunjung

\section{HASIL PENGUJIAN PRASYARAT ANALISIS}

Hasil pengujian persyaratan analisis ini mengenai hasil pengujian dari pengujian normalitas sebaran data, linearitas, multikolinearitas, autokorelasi, dan heterokedastisitas. Secara berturut-turut hasil pengujian persyaratan analisis adalah sebagai berikut:

\section{a. Pengujian Normalitas Sebaran Data}

Pengujian normalitas sebaran data dilakukan dengan menggunakan uji Kolmogorov-Smirnov yang dikenakan terhadap data kualitas pelayanan dan kepuasan pengunjung perpustakaan Undiksha.

Berdasarkan Tabel 4.3 dapat diketahui bahwa hasil pengujian normalitas untuk data kualitas pelayanan menghasilkan nilai Kolmogorov-Smirnov Z yaitu 1,050 dengan signifikansi sebesar 0,220 . Angka signifikansi ini lebih besar dari 0,05 sehingga dikatakan bahwa data kualitas pelayanan berdistribusi normal. Begitu juga hasil pengujian normalitas untuk data kepuasan pengunjungmenghasilkan nilai Kolmogorov-Smirnov Z yaitu 1,262 dengan signifikansi sebesar 0,083. Angka signifikansi ini lebih besar dari 0,05 sehingga dikatakan bahwa data kepuasan pengunjungberdistribusi normal.

\section{b. Uji linearitas}

Hasil analisis uji linieritas garis regresi pada Tabel 4.4 menunjukkan $F$ Deviation from linierity dengan nilai signifikansi $>0,05$. Dengan demikian dapat disimpulkan bahwa korelasi antara variabel kualitas pelayanan (X) dengan kepuasan pengunjung perpustakaan Undiksha mempunyai hubungan yang linier.

\section{c. Uji multikolineritas}

Uji multikolineritas menggunakan uji VIF antara sesama variabel bebas. Kaidah yang digunakan menyatakan kolinier tidaknya antara sesama varibel bebas adalah harga VIF. Jika nilai VIF mendekati 1 maka antara sesama variabel bebas adalah tidak terjadi multikoliaritas (Candiasa, 2004:31).

Dari Tabel 4.5 di atas nilai VIF sama dengan 1 , demikian pula untuk nilai tolerance sama dengan 1. Dengan demikian dapat disimpulkan bahwa dalam regresi antara variabel bebas tidak terjadi multikolineritas.

\section{d. Uji Autokorelasi}

Uji autokorelasi dilakukan dengan tujuan untuk menguji apakah sebuah model regresi linier ada korelasi antara kesalahan pengganggu pada periode " $\mathrm{t}$ " dengan kesalahan pada periode $\mathrm{t}-1$ atau sebelumnya. Jika terjadi korelasi, maka dinamakan ada masalah autokorelasi. 
Model regresi yang baik adalah model regresi yang bebas dari masalah autokorelasi. Pengujian autokorelasi dilakukan dengan menggunakan uji DurbinWatson melalui program SPSS 17 for windows. Apabila nilai uji DurbinWatsonmendekati angka 2, maka dapat dikatakan antara variabel bebas dari masalah autokorelasi. Berdasarkan hasil analisis dapat diketahui bahwa nilai uji Durbin-Watson sebesar 1,888 dan berada mendekati angka 2, maka dapat dikatakan setelah dilakukan uji autokorelasi, pada semua variabel tidak terjadi autokorelasi.

\section{e. Uji Heterokesdastisitas}

Uji heterokesdastisitas dilakukan untuk mengetahui homogenitas antara kelompok data variabel terikat atas masingmasing variabel bebas, dengan kata lain untuk menguji apakah dalam sebuah model regresi terjadi ketidaksamaan varian residual dari suatu pengamatan ke pengamatan yang lain. Model regresi yang baik adalah jika tidak terjadi perbedaan varians. Teknik yang digunakan untuk mencari heterokesdastisitas adalah dengan melihat nilai Studentized Delete Residual menggunakan program SPSS 17 for windows.

Deteksi yang dilakukan dengan melihat ada tidaknya pola tertentu pada grafik di atas, yang mana sumbu $X$ dan $Y$ yang diprediksi dan sumbu $Y$ adalah residual $(Y$ prediksi - $Y$ sesungguhnya) yang telah distandarisasi. Jika ada pola tertentu seperti titik-titik yang ada membuat pola tertentu yang teratur (bergelombang, melebar kemudian menyempit), maka telah terjadi varians yang berbeda. Jika tidak ada pola seperti yang disebutkan di atas, maka akan terjadi varian yang konstan. Dari grafik di atas, dapat dilihat bahwa titik-titik menyebar secara acak, tidak membentuk pola tertentu yang jelas dan menyebar. Hal ini berarti terjadi varian yang konstan, sehingga model regresi layak dipakai untuk memprediksi hubungan antara variabel kualitas pelayanan (X) terhadap kepuasan pengunjung perpustakaan Undiksha.

\section{Hasil Pengujian Hipotesis}

\section{a. Pengaruh bukti langsung (Tangibles) terhadap kepuasan pengunjung}

Hipotesis yang diuji adalah kualitas pelayanan dilihat dari aspek bukti langsung (Tangibles) berpengaruh positif dan siginifikan terhadap kepuasan pengunjung perpustakaan Undiksha. Hipotesis tersebut dijabarkan menjadi:

Ho : $b=0$, artinya tidak ada pengaruh kualitas pelayanan dilihat dari aspek bukti langsung (Tangibles) terhadap kepuasan pengunjung perpustakaan Undiksha.

$\mathrm{Hi}: \mathrm{b} \neq 0$, artinya ada pengaruh kualitas pelayanan dilihat dari aspek bukti langsung (Tangibles) terhadap kepuasan pengunjung perpustakaan Undiksha.

Hipotesis tersebut diuji dengan menggunakan analisis regresi linear sederhana, yang pengerjaannya dengan menggunakan bantuan program SPSS 17.0 FW dan hasilnya sebagai berikut.

Berdasarkan tabel anova regresi di atas, dapat disimpulkan bahwa model regresi memiliki nilai $F_{\text {hitung }}=25,082$ dan signifikansi $(\mathrm{sig})=0,000$. Karena angka signifikansi lebih kecil dari 0,05 maka regresi ini berarti signifikan dan linier. Sehingga dapat dikatakan bahwa ada pengaruh kualitas pelayanan dilihat dari aspek bukti langsung (Tangibles) terhadap kepuasan pengunjung perpustakaan Undiksha. Besarnya korelasi antara kualitas pelayanan dilihat dari aspek bukti langsung (Tangibles) terhadap kepuasan pengunjung perpustakaan Undiksha $r=0,549$ sedangkan kontribusinya sebesar 0,302 atau $30,20 \%$.

\section{b. Pengaruh kehandalan (reliability) terhadap kepuasan pengunjung perpustakaan Undiksha}


Hipotesis yang diuji adalah kualitas pelayanan dilihat dari aspek kehandalan (reliability) berpengaruh positif dan siginifikan terhadap kepuasan pengunjung perpustakaan Undiksha. Hipotesis tersebut dijabarkan menjadi:

Ho : $b=0$, artinya tidak ada pengaruh kualitas pelayanan dilihat dari aspek kehandalan (reliability) terhadap kepuasan pengunjung perpustakaan Undiksha.

$\mathrm{Hi}: \mathrm{b} \neq 0$, artinya ada pengaruh kualitas pelayanan dilihat dari aspek kehandalan (reliability) terhadap kepuasan pengunjung perpustakaan Undiksha.

Hipotesis tersebut diuji dengan menggunakan analisis regresi linear sederhana, yang pengerjaannya dengan menggunakan bantuan program SPSS 17.0 FW dan hasilnya sebagai berikut.

Berdasarkan tabel anova regresi di atas, dapat disimpulkan bahwa model regresi memiliki nilai $F_{\text {hitung }}=60,863$ dan signifikansi (sig) $=0,000$. Karena angka signifikansi lebih kecil dari 0,05 maka regresi ini berarti signifikan dan linier. Sehingga dapat dikatakan bahwa ada pengaruh kualitas pelayanan dilihat dari aspek kehandalan (reliability) terhadap kepuasan pengunjung perpustakaan Undiksha. Besarnya korelasi antara kualitas pelayanan dilihat dari aspek kehandalan (reliability)terhadap kepuasan pengunjung perpustakaan Undiksha $r=0,716$ sedangkan kontribusinya sebesar 0,512 atau 51,20\%.

\section{c. Pengaruh cepat tanggap (responsiveness) terhadap kepuasan pengunjung perpustakaan Undiksha}

Hipotesis yang diuji adalah kualitas pelayanan dilihat dari aspek cepat tanggap (responsiveness)berpengaruh positif dan siginifikan terhadap kepuasan pengunjung perpustakaan Undiksha. Hipotesis tersebut dijabarkan menjadi:

Ho : $b=0$, artinya tidak ada pengaruh kualitas pelayanan dilihat dari aspek cepat tanggap (responsiveness) terhadap kepuasan

pengunjung

perpustakaan

Undiksha.

$\mathrm{Hi}: \mathrm{b} \neq 0$, artinya ada pengaruh kualitas pelayanan dilihat dari aspek cepat tanggap (responsiveness)terhadap kepuasan pengunjung perpustakaan Undiksha.

Berdasarkan tabel anova regresi di atas, dapat disimpulkan bahwa model regresi memiliki nilai $F_{\text {hitung }}=165,966$ dan signifikansi $(\mathrm{sig})=0,000$. Karena angka signifikansi lebih kecil dari 0,05 maka regresi ini berarti signifikan dan linier. Sehingga dapat dikatakan bahwa ada pengaruh kualitas pelayanan dilihat dari aspek cepat tanggap (responsiveness)terhadap kepuasan pengunjung perpustakaan Undiksha. Besarnya korelasi antara kualitas pelayanan dilihat dari aspek cepat tanggap (responsiveness)terhadap kepuasan pengunjung perpustakaan Undiksha $r=$ 0,861 sedangkan kontribusinya sebesar 0,741 atau $74,10 \%$.

\section{d. Pengaruh kepastian/jaminan (assurance) terhadap kepuasan pengunjung perpustakaan Undiksha}

Hipotesis yang diuji adalah kualitas pelayanan dilihat dari aspek kepastian/jaminan (assurance) berpengaruh positif dan siginifikan terhadap kepuasan pengunjung perpustakaan Undiksha. Hipotesis tersebut dijabarkan menjadi:

Ho : $b=0$, artinya tidak ada pengaruh kualitas pelayanan dilihat dari aspek kepastian/jaminan (assurance) terhadap kepuasan pengunjung perpustakaan Undiksha.

$\mathrm{Hi}: \mathrm{b} \neq 0$, artinya ada pengaruh kualitas pelayanan dilihat dari aspek kepastian/jaminan (assurance) terhadap kepuasan pengunjung perpustakaan Undiksha.

Hipotesis tersebut diuji dengan menggunakan analisis regresi linear sederhana, yang pengerjaannya dengan 
menggunakan bantuan program SPSS 17.0 FW dan hasilnya sebagai berikut.

Berdasarkan tabel anova regresi di atas, dapat disimpulkan bahwa model regresi memiliki nilai $F_{\text {hitung }}=22,778$ dan signifikansi $(\mathrm{sig})=0,000$. Karena angka signifikansi lebih kecil dari 0,05 maka regresi ini berarti signifikan dan linier. Sehingga dapat dikatakan bahwa ada pengaruh kualitas pelayanan dilihat dari aspek kepastian/jaminan (assurance) terhadap kepuasan pengunjung perpustakaan Undiksha. Besarnya korelasi antara kualitas pelayanan dilihat dari aspek kepastian/jaminan (assurance) terhadap kepuasan pengunjung perpustakaan Undiksha $r=0,531$ sedangkan kontribusinya sebesar 0,282 atau $28,20 \%$.

\section{e. Pengaruh empati (empaty) terhadap kepuasan pengunjung perpustakaan Undiksha}

Hipotesis yang diuji adalah kualitas pelayanan dilihat dari aspek empati (empaty) berpengaruh positif dan siginifikan terhadap kepuasan pengunjung perpustakaan Undiksha. Hipotesis tersebut dijabarkan menjadi:

Ho : $b=0$, artinya tidak ada pengaruh kualitas pelayanan dilihat dari aspek empati (empaty) terhadap kepuasan pengunjung perpustakaan Undiksha.

$\mathrm{Hi}: \mathrm{b} \neq 0$, artinya ada pengaruh kualitas pelayanan dilihat dari aspek empati (empaty) terhadap kepuasan pengunjung perpustakaan Undiksha.

Hipotesis tersebut diuji dengan menggunakan analisis regresi linear sederhana, yang pengerjaannya dengan menggunakan bantuan program SPSS 17.0

Dapat disimpulkan bahwa model regresi memiliki nilai $F_{\text {hitung }}=111,805$ dan signifikansi $(\mathrm{sig})=0,000$. Karena angka signifikansi lebih kecil dari 0,05 maka regresi ini berarti signifikan dan linier. Sehingga dapat dikatakan bahwa ada pengaruh kualitas pelayanan dilihat dari aspek empati (empaty) terhadap kepuasan pengunjung perpustakaan Undiksha. Besarnya korelasi antara kualitas pelayanan dilihat dari aspek empati (empaty) terhadap kepuasan pengunjung perpustakaan Undiksha $r=$ 0,881 sedangkan kontribusinya sebesar 0,658 atau $65,80 \%$.

\section{f. Pengaruh kualitas pelayanan terhadap kepuasan pengunjung perpustakaan Undiksha}

Hipotesis yang diuji adalah kualitas pelayanan berpengaruh positif dan siginifikan terhadap kepuasan pengunjung perpustakaan Undiksha. Hipotesis tersebut dijabarkan menjadi:

Ho : $b=0$, artinya tidak ada pengaruh kualitas pelayanan terhadap kepuasan pengunjung perpustakaan Undiksha.

$\mathrm{Hi}: \mathrm{b} \neq 0$, artinya ada pengaruh kualitas pelayanan terhadap kepuasan pengunjung perpustakaan Undiksha.

Hipotesis tersebut diuji dengan menggunakan analisis regresi linear ganda, yang pengerjaannya dengan menggunakan bantuan program SPSS 17.0 FW dan hasilnya sebagai berikut.

Berdasarkan tabel anova regresi di atas, dapat disimpulkan bahwa model regresi memiliki nilai $\mathrm{F}_{\text {hitung }}=104,217$ dan signifikansi $(\mathrm{sig})=0,000$. Karena angka signifikansi lebih kecil dari 0,05 maka regresi ini berarti signifikan dan linier. Sehingga dapat dikatakan bahwa ada pengaruh kualitas pelayanan terhadap kepuasan pengunjung perpustakaan Undiksha. Besarnya korelasi antara kualitas pelayanan terhadap kepuasan pengunjung perpustakaan Undiksha $r=0,952$ sedangkan kontribusinya sebesar 0,906 atau $90,60 \%$. 


\section{PEMBAHASAN}

Sebelum dilakukan pengujian hipotesis, maka data yang diperoleh dianalisis terlebih dahulu dengan menggunakan analisis deskriptif. Setelah itu, baru dilanjutkan dengan analisis untuk pengujian hipotesis.Dari hasil pengujian hipotesis diperoleh beberapa hal yaitu sebagai berikut.

Pertama, untuk hubungan $\mathrm{x} 1 \mathrm{Y}$ diperoleh nilai $F_{\text {hitung }}=25,082$ dan signifikansi $(\mathrm{sig})=0,000$. Karena angka signifikansi lebih kecil dari 0,05 maka regresi ini berarti signifikan dan linier. Sehingga dapat dikatakan bahwa ada pengaruh kualitas pelayanan dilihat dari aspek bukti langsung (Tangibles) terhadap kepuasan pengunjung perpustakaan Undiksha. Besarnya korelasi antara kualitas pelayanan dilihat dari aspek bukti langsung (Tangibles) terhadap kepuasan pengunjung perpustakaan Undiksha $r=0,549$ sedangkan kontribusinya sebesar 0,302 atau $30,20 \%$.

Kedua, untuk hubungan $\mathrm{x} 2 \mathrm{Y}$, diperoleh nilai $F_{\text {hitung }}=60,863$ dan signifikansi $($ sig) $=0,000$. Karena angka signifikansi lebih kecil dari 0,05 maka regresi ini berarti signifikan dan linier. Sehingga dapat dikatakan bahwa ada pengaruh kualitas pelayanan dilihat dari aspek kehandalan (reliability) terhadap kepuasan pengunjung perpustakaan Undiksha. Besarnya korelasi antara kualitas pelayanan dilihat dari aspek kehandalan (reliability) terhadap kepuasan pengunjung perpustakaan Undiksha $r=0,716$ sedangkan kontribusinya sebesar 0,512 atau $51,20 \%$.

Ketiga, untuk hubungan $\times 3 Y$ diperoleh nilai $F_{\text {hitung }}=165,966$ dan signifikansi $(\mathrm{sig})=0,000$. Karena angka signifikansi lebih kecil dari 0,05 maka regresi ini berarti signifikan dan linier. Sehingga dapat dikatakan bahwa ada pengaruh kualitas pelayanan dilihat dari aspek cepat tanggap (responsiveness) terhadap kepuasan pengunjung perpustakaan Undiksha. Besarnya korelasi antara kualitas pelayanan dilihat dari aspek cepat tanggap (responsiveness)terhadap kepuasan pengunjung perpustakaan Undiksha $r=$ 0,861 sedangkan kontribusinya sebesar 0,741 atau $74,10 \%$.

Keempat, untuk hubungan $\mathrm{x} 4 \mathrm{Y}$ diperoleh nilai $F_{\text {hitung }}=22,778$ dan signifikansi $(\mathrm{sig})=0,000$. Karena angka signifikansi lebih kecil dari 0,05 maka regresi ini berarti signifikan dan linier. Sehingga dapat dikatakan bahwa ada pengaruh kualitas pelayanan dilihat dari aspek kepastian/jaminan (assurance) terhadap kepuasan pengunjung perpustakaan Undiksha. Besarnya korelasi antara kualitas pelayanan dilihat dari aspek kepastian/jaminan (assurance) terhadap kepuasan pengunjung perpustakaan Undiksha $r=0,531$ sedangkan kontribusinya sebesar 0,282 atau 28,20\%.

Kelima, untuk hubungan $\mathrm{x} 5 \mathrm{Y}$ diperoleh nilai $F_{\text {hitung }}=111,805$ dan signifikansi $(\mathrm{sig})=0,000$. Karena angka signifikansi lebih kecil dari 0,05 maka regresi ini berarti signifikan dan linier. Sehingga dapat dikatakan bahwa ada pengaruh kualitas pelayanan dilihat dari aspek empati (empaty) terhadap kepuasan pengunjung perpustakaan Undiksha. Besarnya korelasi antara kualitas pelayanan dilihat dari aspek empati (empaty) terhadap kepuasan pengunjung perpustakaan Undiksha $r=$ 0,881 sedangkan kontribusinya sebesar 0,658 atau $65,80 \%$.

Keenam, untuk hubungan $\mathrm{XY}$ diperoleh nilai $F_{\text {hitung }}=104,217$ dan signifikansi $(\mathrm{sig})=0,000$. Karena angka signifikansi lebih kecil dari 0,05 maka regresi ini berarti signifikan dan linier. Sehingga dapat dikatakan bahwa ada pengaruh kualitas pelayanan terhadap kepuasan pengunjung perpustakaan Undiksha. Besarnya korelasi antara kualitas pelayanan terhadap kepuasan pengunjung perpustakaan Undiksha $r=0,952$ sedangkan kontribusinya sebesar 0,906 atau $90,60 \%$.

Timbul pertanyaan yang harus diberikan penjelasan mengapa kualitas 
pelayanan berpengaruh terhadap kepuasan pengunjung perpustakaan Undiksha.

Kepuasan

pengunjung perpustakaan Undiksha dipengaruhi oleh kualitas pelayanan yang diberikan oleh perpustakaan.Kualitas jasa/pelayanan dapat diukur melalui beberapa dimensi yaitu (a) Tangibles I bukti langsung,

Reliability/kehandalan, (c) Responsiviness/ daya tanggap, (d) Assurens/ jaminan, (e) emphaty/empati. Kelima hal tersebut merupakan keinginan dari sebagian pengunjung perpustakaan terhadap pelayanan yang dapat dipercaya, pihak perpustakaan dapat mewujudkan kepuasan pengunjung perpustakaan dengan memberikan pelayanan yang dijanjikan dengan tepat, akurat, segera dan tepat waktu sesuai dengan yang dijanjikan dan memuaskan kepada semua pengunjung perpustakaan. Maka bukti langsung, kehandalan, daya tanggap, kepastian dan empati harus bisa menjadi warna dari seluruh pelayanan perpustakaan, mulai dari produk, proses pelayanan informasi, sumber daya manusia sebagai pelayanan terhadap mahasiswa.

Pelayanan yang berkualitas
tercermin dari kemampuan petugas
pelayanan perpustkaan untuk memberikan
jasa yang dijanjikan dengan tepat dan
terpercaya (Reliability), kemampuan terpercaya (Reliability), kemampuan
pelayanan untuk membantu pelanggan dan memberikan jasa dengan cepat (Responsiveness), pengetahuan dan kesopanan karyawan serta kemampuan mereka untukmenimbulkan kepercayaan dan jaminan kepastian (Assurance), kepedulian karyawan untuk memberikan perhatian pribadi bagi pelanggan (Empathy), dan penampilan fisik, peralatan, personil dan media komunikasi (Tangibles). Kelima dimensi kualitas pelayanan tersebut pada akhirnya akan dinilai oleh mahasiswa sebagai pengunjung perpustakaan dan tentunya memberikan pengaruh terhadap kepuasan pengunjung perpustakaan.

\section{SIMPULAN DAN SARAN \\ SIMPULAN}

Berdasarkan hasil penelitian dan pembahasan, maka dapat ditarik beberapa simpulan dari penelitian ini antara lain sebagai berikut.

1. Ada hubungan kualitas pelayanan dilihat dari aspek bukti langsung (Tangibles) terhadap kepuasan pengunjung perpustakaan Undiksha. Besarnya korelasi antara kualitas pelayanan dilihat dari aspek bukti langsung (Tangibles) terhadap kepuasan pengunjung perpustakaan Undiksha $r=0,549$ sedangkan kontribusinya sebesar 0,302 atau $30,20 \%$.

2. Ada hubungan kualitas pelayanan dilihat dari aspek kehandalan (reliability) terhadap kepuasan pengunjung perpustakaan Undiksha. Besarnya korelasi antara kualitas pelayanan dilihat dari aspek kehandalan (reliability)terhadap kepuasan pengunjung perpustakaan Undiksha $r=$ 0,716 sedangkan kontribusinya sebesar 0,512 atau $51,20 \%$.

3. Ada hubungan kualitas pelayanan dilihat dari aspek cepat tanggap (responsiveness) terhadap kepuasan pengunjung perpustakaan Undiksha. Besarnya korelasi antara kualitas pelayanan dilihat dari aspek cepat tanggap (responsiveness) terhadap kepuasan pengunjung perpustakaan Undiksha $r=0,861$ sedangkan kontribusinya sebesar 0,741 atau $74,10 \%$.

4. Ada hubungan kualitas pelayanan dilihat dari aspek kepastian/jaminan (assurance) terhadap kepuasan pengunjung perpustakaan Undiksha. Besarnya korelasi antara kualitas pelayanan dilihat dari aspek kepastian/jaminan (assurance) terhadap kepuasan pengunjung perpustakaan Undiksha $r=0,531$ sedangkan kontribusinya sebesar 0,282 atau $28,20 \%$. 
5. Ada hubungan kualitas pelayanan dilihat dari aspek empati (empaty) terhadap kepuasan pengunjung perpustakaan Undiksha. Besarnya korelasi antara kualitas pelayanan dilihat dari aspek empati (empaty) terhadap kepuasan pengunjung perpustakaan Undiksha $r=$ 0,811 sedangkan kontribusinya sebesar 0,658 atau $65,80 \%$.

6. Ada pengaruh kualitas pelayanan terhadap kepuasan pengunjung perpustakaan Undiksha. Besarnya korelasi antara kualitas pelayanan terhadap kepuasan pengunjung perpustakaan Undiksha $r=0,952$ sedangkan kontribusinya sebesar 0,906 atau $90,60 \%$.

\section{SARAN}

Berdasarkan hasil penelitian dan pembahasan, maka saran-saran yang diajukan antara lain.

1. Perpustakaan Undiksha agar tetap mempertahankan hasil positif yang telah didapat dalam memberikan layanan kepada para penggunanya;

2. Perpustakaan Undiksha agar lebih bisa meningkatkan kinerja dalam melayani pengunjung perpustakaan sehingga pengunjung akan merasa puas mendapatkan pelayanan

\section{DAFTAR PUSTAKA}

Adrian, P. 1993. The essence of service marketing. USA: Prantice Hall-Europe

Cook, C. \& Heath, F. 2000. Users perception of library service quality: A LIBQUAL qualitative study: Washington DC: $A R L$ Measuring Service Quality Symposium. Tersedia pada www.arl.org/libqual/event/oct2000ms g/papers/HeatCook/heatcook.html. Diakses pada tanggal 14 Februari 2011

Dharma, Nyoman Oka (2009). Evaluasi Kualitas Layanan di Perpustakaan
Undiksha berdasarkan Metode Servqual. Laporan Penelitian.

Hadi, Sutrisno. 2001. Analisis Regresi. Yogyaakarta: Andi

Kaihatu, T. S. 2008. Analisa kesenjangan kualitas pelayanan dan kepuasan konsumen pengunjung Plaza Tunjungan Surabaya. Jurnal Manajemen dan Kewirausahaan. 10(1): 66-83.

Kertajaya, H. t.t. The 10 credos of compassionate marketing Tersedia pada (www.markplusnco.com) Diakses pada tanggal 11 Februari 2011

Kotler, P. 1997. Manajemen pemasaran jilid I. Jakarta: PT Prenhallindo

Mulanjari, S. 1999. Persepsi pemakai terhadap kualitas jasa layanan perpustakaan Universitas Indonesia. Tesis. (Tidak Diterbitkan). Universitas Indonesia.

Mulyadi. 2001. Alat manajemen kontemporer untuk pelipatgandaan kinerja keuangan perusahaan: balance scorecard. Jakarta: Salemba Empat

Parasuraman, Z. \& Berry. 1985. A conceptual model of service quality and its implication for future research. Journal of Marketing. 49(1): 1-12

Parasuraman, Z. \& Berry. 1988. Servqual: A multiple-item ccale for measuring customer perceptions of service quality. Journal of Retailing, 64(1) : 24-31

Parasuraman, Z. \& Berry. 1990. Delivering service quality, New York: Free Press

Renborg, G. 2010. Marketing library service: how it all began (s.I.) Journal IFLA. 63. Tersedia pada (www.ifla.org//V/ifla63reng.htm) Diakses pada tanggal 12 Februari 2011

Jurnal IImu Sosial dan Humaniora | 237 
Samosir, Z.Z. 2010. Pengaruh kualitas pelayanan terhadap kepuasan mahasiswa menggunakan perpustakaan USU; Pustaha: Jurnal Stusi Perpustakaan dan informasi. 1(1): $57-65$

Stanton W. J. 1992. Dasar-dasar pemasaran. Jilid I. Jakarta: Erlangga

Sugiyono. 2002. Metode penelitian bisnis., Bandung: Alpabeta

Surtiawan, D. 2006. Kepuasan pemakai dan peningkatan kualitas berbasis pemakai: pendekatan manajemen pemasaran sebagai paradigma paru perpustakaan. Laporan penelitian. (tidak diterbitkan). Universitas Negeri Yogyakarta.

Sutama, I Wayan. 2010. Studi Korelasional Supervisi Pembelajaran, Kompetensi Manajerial Kepala Sekolah dan Kemampuan Kepala Sekolah Memotivasi Guru dengan Kemampuan Manajerial Guru SMK Negeri di Kabupaten Gianyar. Thesis. (tidak diterbitkan). Universitas Pendidikan Ganesha.

Tjiptono, F. \& Diana, A. 1998. Total quality manajemen. Yogyakarta: Andi Offset

Tjiptono, F. 2001. Manajemen pemasaran jasa, Yogyakarta: Andi Offset. 